\title{
IDENTIFIKASI KELAYAKAN RUANG SEMPADAN REL DI MEJING DAN SEDAYU, YOGYAKARTA SEBAGAI RUANG PUBLIK
}

\author{
Adinda Rafika Dani \\ Program Studi Arsitektur, Fakultas Sains dan Teknologi, Universitas PGRI Yogyakarta, \\ Jl. IKIP PGRI I Sonosewu No. 117 \\ Sonosewu, Ngestiharjo, Kasihan, Bantul, D.I. Yogyakarta \\ Email: adinda.rafika@gmail.com
}

\begin{abstract}
Abstrak
Keberadaan ruang publik dalam suatu kawasan/kota sangatlah penting. Selain berfungsi sebagai landmark kawasan, ruang terbuka juga berfungsi sebagai area interaksi masyarakat. Penelitian ini bertujuan untuk mengidentifikasi kelayakan area lost space ruang sempadan rel kereta api di Mejing dan Sedayu sebagai ruang publik. Metode penelitian yang dilakukan adalah dengan melakukan survey dan wawancara masyarakat yang memanfaatkan kedua ruang sempadan rel ini. Variabel survey yang digunakan yaitu kenyamanan, relaksasi, passive engagement, active engagement dan discovery. Hasil penelitian menemukan bahwa ruang publik di sempadan rel Mejing, jika dilihat dari segi kenyamanan mendapatkan penilaian yang kurang baik dengan persentase $47,62 \%$, sedangkan di Sedayu mendapatkan penilaian hampir sama, yaitu kurang baik dengan persentase sebesar $43,14 \%$. Jika dilihat dari indikator relaxation, ruang terbuka di sempadan rel Mejing dan Sedayu mendapat penilaian baik dengan persentase $52,53 \%$ dan $52,67 \%$. Sedangkan tingkat keamanan ruang terbuka di sempadan rel Mejing menyatakan penilaian baik dengan rata-rata persentase $53,17 \%$ dan di sempadan rel Sedayu mendapatkan penilaian kurang baik dengan nilai persentase $42,17 \%$. Faktor rendahnya kelayakan ruang terbuka di sempadan rel kereta api yang terjadi adalah kurangnya fasilitas, kebersihan, pengelolaan parkir dan kenyamanan pengguna ruang terbuka.
\end{abstract}

Kata kunci: kelayakan, ruang publik, sempadan rel.

\section{Abstract \\ Title: Feasibility Identification of the Railway Track Setback in Mejing and Sedayu, Yogyakarta for a Public Space}

The availability of public space in an urban area/city is very important. Apart from functioning as regional landmarks, open spaces also function as areas for community interaction. This study aims to identify the feasibility of the lost space area along the railroad boundaries in Mejing and Sedayu as a public space. The research method used is to conduct surveys and interviews with people who use these two railway track border spaces. The survey variables used are comfort, relaxation, passive engagement, active engagement and discovery. The results of the study found that the public space on the Mejing railway track border, from the point of view of comfort, received a poor rating with a percentage of $47.62 \%$, while in Sedayu it received almost the same rating, which was not good with a percentage of $43.14 \%$. When viewed from the relaxation indicator, the open space on the border of Mejing and Sedayu rails received a good rating with a percentage of $52.53 \%$ and $52.67 \%$. Meanwhile, the level of open space security at the Mejing railway track border stated that the assessment was good with an average percentage of $53.17 \%$ and at the Sedayu rail border received a poor rating with a percentage value of $42.17 \%$. The factor of the low feasibility of open space at the railroad border is a lack of facilities, cleanliness, parking management and the comfort of open space users.

Keywords: properness, public area, railroad line. 


\section{Pendahuluan}

Ruang terbuka publik merupakan sebuah area fasilitas sebuah kota atau wilayah yang memenuhi kebutuhan masyarakatnya untuk berinteraksi. Dalam UU RI tahun 2007 Pasal 29 disebutkan bahwa proporsi ruang terbuka hijau publik pada wilayah kota paling sedikit adalah 20 (dua puluh) persen dari luas wilayah. Di pasal 28 dijelaskan bahwa perlunya penyediaan dan pemanfaatan ruang terbuka hijau dan non-hijau guna penyediaan prasarana dan sarana jaringan pejalan kaki, angkutan umum, kegiatan sektor informal, dan evakuasi bencana untuk mendukung pertumbuhan wilayah.

Menurut Edy Darmawan (2009), ruang publik dari sebuah kota dapat memberikan karakter tersendiri yang pada umumnya memiliki fungsi interaksi sosial bagi masyarakat, kegiatan ekonomi rakyat dan tempat untuk apresiasi budaya. Sedangkan menurut Rustam Hakim (1987), ruang terbuka adalah ruang yang bisa diakses oleh masyarakat baik secara langsung dalam kurun waktu terbatas maupun secara tidak langsung dalam kurun waktu tertentu. Sehingga dapat dikatakan bahwa ruang terbuka publik merupakan sebuah ruang yang dapat diakses oleh semua kalangan masyarakat dengan memanfaatkan ruang publik untuk segala macam kegiatan baik individual atau berkelompok. Kebebasan bagi masyarakat untuk melakukan kegiatan itulah terkadang perlu pengendalian aktivitas-aktivitas yang terjadi, perlu pengaturan fungsi ruang, sirkulasi lalu lintas dan parkir kendaraan bermotor, perlu penempatan pedagang kaki lima dan sebagainya.

Berkaitan dengan ruang terbuka publik, terdapat fenomena menarik yang terjadi di Yogyakarta, dimana masyarakat memanfaatkan area sempadan rel kereta api, tepatnya pada area perlintasan sebidang sebagai sebuah ruang terbuka publik. Perlintasan sebidang kereta api menurut perpotongan antara jalur kereta api dengan bangunan lain yang pada umumnya jalan raya. Daerah Istimewa Yogyakarta dilintasi oleh jalur kereta yang membujur membelah wilayah. Dalam peraturan, ruang sempadan rel merupakan wilayah kepemilikan PT KAI. Namun di beberapa tempat, banyak wilayah sempadan rel ini yang menjadi area lost space. Lintasan jalur kereta api yang melewati Yogyakarta ini, terdapat titik-titik perlintasan sebidang yang dimanfaatkan oleh masyarakat sebagai ruang terbuka publik. Diantaranya adalah perlintasan sempadan rel di Mejing dan sempadan rel di Sedayu.

Kedua area sempadan rel ini pada jamjam tertentu terutama sore hari, akan terbentuk keramaian dimana terdapat beberapa aktivitas yang dilakukan oleh warga. Diantaranya adalah dudukduduk melihat kereta api dan berinteraksi, anak-anak yang bermain di area bermain yang disediakan PKL, dan kegiatan kuliner karena banyak PKL jajanan yang berada di kanan kiri sempadan rel kereta api.

Kebutuhan masyarakat di sekitar sempadan rel kereta Mejing dan Sedayu untuk berinteraksi, membuat area lost space berubah fungsi menjadi sebuah ruang terbuka publik. Sedangkan permasalahan utama sebuah ruang terbuka publik adalah ketersediaan fasilitas dan prasarana yang aman dan nyaman sebagai sebuah ruang untuk berinteraksi. Sempadan rel Mejing dan Sedayu memiliki potensi yang dapat dikembangkan sebagai sebuah ruang terbuka publik yang aman dan nyaman. Oleh karena itu, penelitian ini dilakukan 
untuk mengidentifikasi kelayakan area terbuka publik yang terjadi di sempadan rel Mejing dan Sedayu.

\section{Metode}

Metode penelitian yang digunakan adalah metode kuantitatif survei dengan mengambil sampel dari populasi target pengunjung di Ruang Terbuka Sempadan Rel Kereta di Mejing dan Sedayu. Instrumen data diperoleh melalui penyebaran kuesioner yang diisi oleh responden atau wawancara terstruktur yang hasilnya diolah dan digeneralisasi terhadap populasi tertarget. Target minimal responden adalah 50 responden pada setiap lokus penelitian.

Variabel yang digunakan pada penelitian ini adalah unsur-unsur ruang publik yang dikemukakan oleh Carmona (2004) antara lain: comfort, relaxation, passive engagement, active engagement dan discovery. Kemudian variabel tersebut disesuaikan dengan lokus penelitian yang menghasilkan indikator untuk penilaian fenomena yang terjadi. (lihat tabel 1).

Tabel 1. Variabel penelitian

\begin{tabular}{|l|l|l|}
\hline \multicolumn{1}{|c|}{ Variabel } & \multicolumn{1}{|c|}{ Indikator } & \multicolumn{1}{|c|}{ Instrumen } \\
\hline \multirow{5}{*}{ Comfort } & Jumlah tanaman & Kuesioner \\
\cline { 2 - 3 } & Sarana tempat sampah & Kuesioner \\
\cline { 2 - 3 } & Fasilitas tempat duduk & Kuesioner \\
\cline { 2 - 3 } & Fasilitas lampu penerangan & Kuesioner \\
\cline { 2 - 3 } & Kapasitas parkir & Kuesioner \\
\cline { 2 - 3 } & Pengelolaan parkir & Kuesioner \\
\cline { 2 - 3 } & Kondisi perkerasan & Kuesioner \\
\cline { 2 - 3 } & Penataan PKL & Kuesioner \\
\hline Relaxation & Area yang meneduhkan & Skala \\
\cline { 2 - 3 } & Tatanan dan kerapian tanaman & Skala \\
\cline { 2 - 3 } & Kebersihan area & Skala \\
\cline { 2 - 3 } & Menikmati suasana & Skala \\
\cline { 2 - 3 } & Keinginan untuk menghabiskan waktu & Wawancara \\
\hline Passive enggagement & Kegiatan yang dilakukan di lokus & Wawancara \\
\hline Active enggagement & Tujuan datang ke lokus & Wawancara \\
\hline Discovery & Keamanan area untuk area bermain & Wawancara \\
\cline { 2 - 3 } & Kemudahan pengawasan anak bermain & \\
\cline { 2 - 3 } & Kenyamanan sebagai tempat berkumpul & Wara \\
\cline { 2 - 3 } & Keamanan sebagai tempat berkumpul & Wawancara \\
\hline
\end{tabular}

Sumber: Analisis penulis 
Skala penilaian yang digunakan untuk pengumpulan data bersifat ordinal dengan skala Likert. Dalam penelitian ini pemberian skor menggunakan skala Likert yaitu dengan menghadapkan seorang responden dengan sebuah pernyataan dan kemudian diminta untuk memberikan penilaian jawaban "kurang baik", "baik", "sangat baik" dan "abstain" untuk yang tidak menjawab pertanyaan di kuesioner.

Analisis data yang dilakukan dalam penelitian ini melalui analisis kuantitatif penyajian tabel statistik dan tahap pengolahan datanya dengan penafsiran data, reduksi data, penyusunan data, pemeriksaan keabsahan data kemudian terakhir menarik kesimpulan. Pada bagian akhir analisis untuk menarik kesimpulan, skala Likert yang diberlakukan untuk penilaian kuesioner dirincikan menjadi skala angka dengan penilaian "abstain = 0 ", "kurang baik $=1$ ", "baik = 2" dan "sangat baik $=3$ ".

Kemudian, dari masing-masing variabel di atas, indikator masingmasing akan disejajarkan agar bisa diidentifikasi penilaian yang setara. Rentang penilaian yang digunakan adalah antara $0 \%-25 \%$ status average nya abstain, $25.1 \%-50 \%$ status average kurang baik, $50.1 \%-75 \%$ status average baik, sedangkan $75.1 \%-100 \%$ status average sangat baik.

\section{Hasil dan Pembahasan}

\section{Gambaran Umum Responden}

Jumlah respoden untuk lokus sempadan rel kereta di Sedayu dan Mejing yaitu total 100 orang, dengan pembagian masing-masing 50 orang responden. Rincian berdasarkan jenis kelaminnya sebagai berikut:

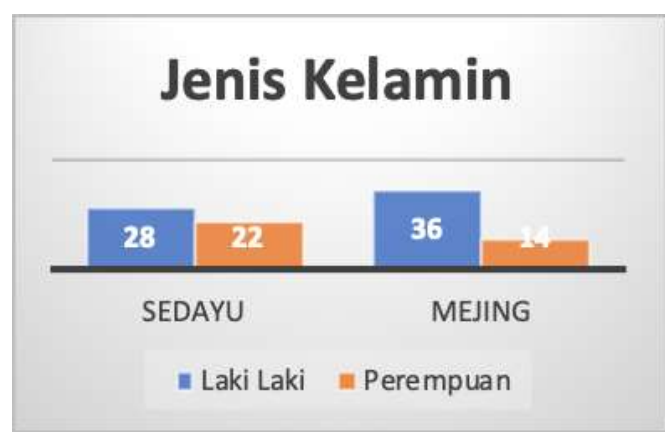

\section{Gambar 1. Pengelompokan responden berdasarkan jenis kelamin Sumber: Hasil analisis penulis}

Dari hasil survey yang dilakukan, jumlah pengunjung di lokus Mejing dan Sedayu lebih banyak jumlah pengunjung Mejing, dikarenakan lokasi sempadan rel Mejing merupakan perlintasan menuju area perkotaan dan disekitarnya merupakan permukiman warga. Akan tetapi dalam pengambilan responden ini, penulis membagi rata jumlah sampel responden agar data yang didapatkan bisa setara.

Pengumpulan data dari penelitian ini dilakukan dengan instrumen kuesioner, skala dan wawancara secara langsung kepada responden untuk menggali informasi yang dicari. Penyajian data mengenai profil responden sebagai data penunjang yang terdiri dari atas umur, pendidikan dan jenis pekerjaan adalah sebagai berikut: 

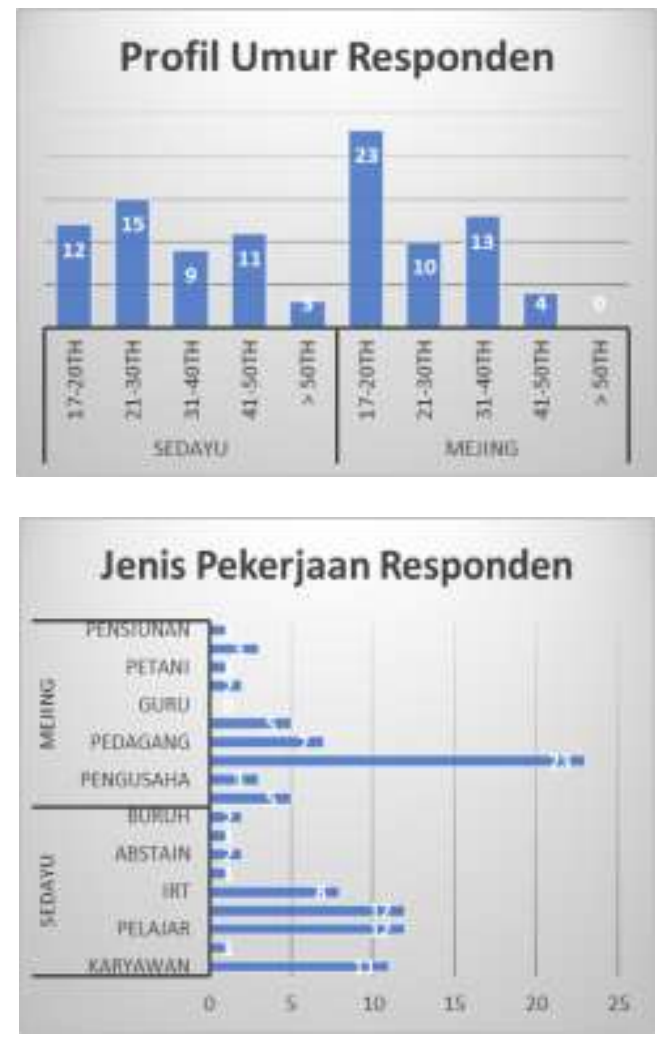

Gambar 2. Pengelompokan responden berdasarkan umur dan pekerjaan Sumber: Hasil analisis penulis

\section{Comfort (Kenyamanan)}

Jumlah tanaman di sebuah ruang publik menjadi salah satu tolok ukur dalam Ruang Terbuka Hijau. Tumbuhtumbuhan yang berada di Kawasan tersebut selain sebagai sumber peningkatan kadar oksigen juga menjadi tempat rekreasi masyarakat karena keindahan vegetasi hijau yang ada (Rahmadi, 2017). Kasus jumlah tanaman di ruang sempadan rel di Mejing dan Sedayu ini juga hampir sama, berikut tanggapan masyarakat yang telah diolah mengenai kenyamanan beraktivitas di sempadan rel berkaitan dengan jumlah tanaman yang ada di lokasi.

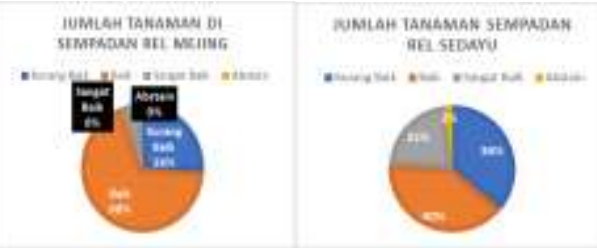

Gambar 3. Penilaian masyarakat tentang jumlah tanaman

Sumber: Hasil analisis penulis

Hasil tanggapan masyarakat tentang Kenyamanan jumlah tanaman mayoritas responden memberikan penilaian yang baik dengan kenyamanan jumlah tanaman baik di sempadan Mejing dan Sedayu, yaitu sebesar $68 \%$ untuk sempadan rel Mejing, dan $40 \%$ untuk sempadan rel di Sedayu. Sebagaimana area sempadan rel yang sesuai dengan peraturan pemerintah, tanaman yang berada di dekat sempadan rel, tidak lebih tinggi dari satu meter diukur dari perkerasan.

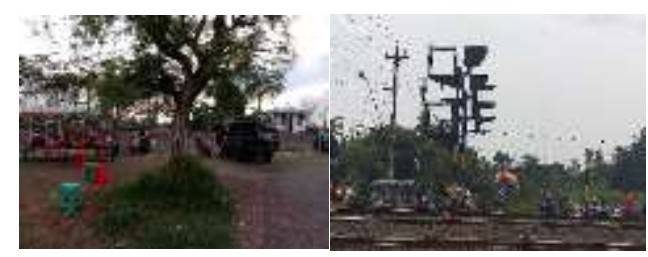

Gambar 4. Penghijauan di lokus Sumber: Dokumentasi penulis

Penilaian kedua dari jumlah tanaman di lokus mendapatkan respon kurang baik sebesar $26 \%$ untuk sempadan rel Mejing dan 36\% untuk sempadan rel Sedayu. Mengingat kegiatan yang banyak dilakukan oleh responden di area sempadan rel ini adalah kegiatan rekreasi sore hari dan kuliner pinggir jalan. Angka kenyamanan jumlah tanaman yang kurang baik ini termasuk besar karena sebagian besar dari pengunjung, tidak segera pergi dari lokasi setelah melakukan kuliner pinggir jalan. Sebagian penjual makanan juga memilih spot yang berada di sekitar tanaman agar lebih teduh pada saat berjualan. 
Fasilitas tempat sampah juga menjadi salah satu faktor kenyamanan bagi pengunjung area ruang terbuka sempadan rel. Karena sebagian aktivitas di lokus adalah wisata kuliner, jadi tidak menutupi kemungkinan untuk pengunjung juga menikmati kuliner di tempat. Sampah menjadi salah satu hasil kegiatan ini. Apabila tidak difasilitasi dengan tempat sampah, tentunya kenyamanan pengunjung akan terganggu karena akan kebingungan membuang sampah. Atau apabila tidak difasilitasi tempat sampah, pengunjung akan membuang sampah sembarangan, hal ini tentunya juga menentukan kenyamanan area publik.

Hasil penilaian responden mengenai fasilitas tempat sampah yang tersedia di lokasi adalah sebagai berikut:

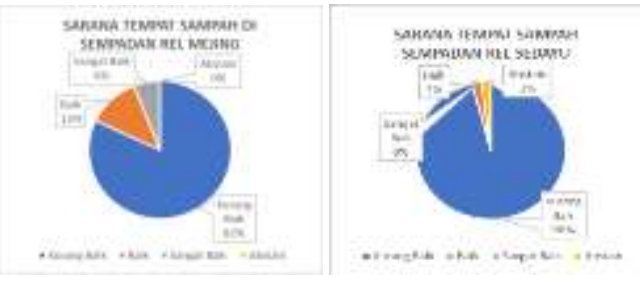

Gambar 5. Penilaian masyarakat tentang kebersihan

Sumber: Hasil analisis penulis

Dari hasil penilaian, sebagian besar responden menilai sarana tempat sampah di sempadan rel Mejing dan Sedayu kurang baik dengan penilaian 82\% di sempadan rel Mejing dan 96\% (hampir seluruh responden) di sempadan rel Sedayu. Pada keadaan eksisting, tempat sampah tidak terfasilitasi dengan baik. Di sempadan rel Mejing hanya ada 2 buah tempat sampah yang ada di sekitar rel kereta. Sedangkan di sempadan rel Sedayu tidak ada fasilitas tempat sampah.

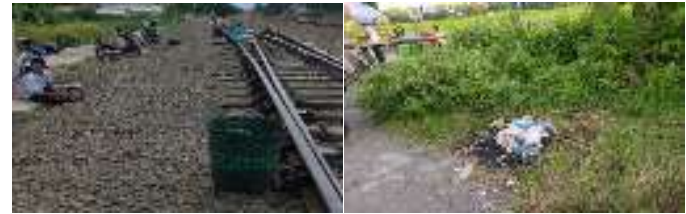

Gambar 6. Kebersihan lokasi penelitian Sumber: Dokumentasi penulis

Indikator penilaian untuk fasilitas tempat duduk di sempadan rel kereta Mejing dan Sedayu adalah sebagai berikut:

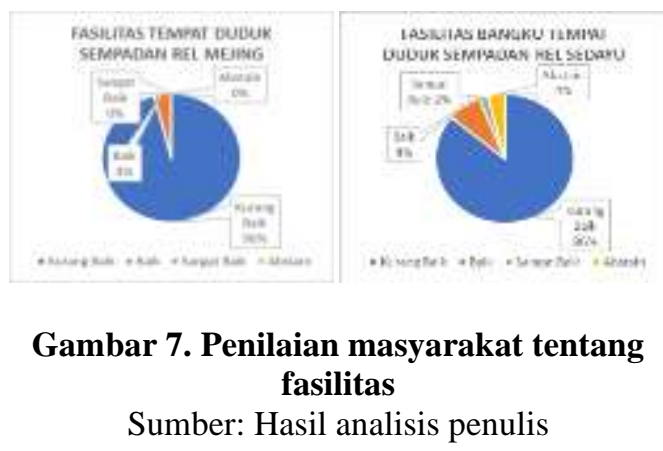

Responden menilai bahwa fasilitas tempat duduk baik di sempadan rel Mejing dan Sedayu kurang baik dengan nilai $96 \%$ untuk sempadan rel Mejing dan $86 \%$ di sempadan rel Sedayu. Pada kondisi eksisting, pengunjung yang menghabiskan waktu di sekitar sempadan rel, beraktivitas dan duduk duduk di rel kereta. Di ruang publik sempadan rel Sedayu, disediakan beberapa tempat duduk dari plastik, akan tetapi tempat duduk tersebut bukan fasilitas umum yang dapat digunakan oleh semua orang, melainkan tempat duduk untuk menunggu anak-anak yang menggunakan arena bermain trampolin.

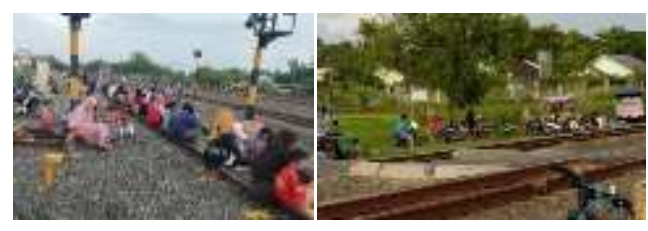

Gambar 8. Tempat duduk di lokus Sumber: Dokumentasi penulis 
Fasilitas penerangan juga salah satu indikator yang mempengaruhi kenyamanan responden di area ruang publik sempadan rel, karena aktivitas yang terjadi di ruang publik sempadan rel ini tidak hanya berlangsung di siang menuju sore hari saja, akan tetapi ada beberapa aktivitas yang masih berlangsung di area ini selepas sore. Berikut penilaian responden yang dihasilkan dari hasil survey yang dilakukan:

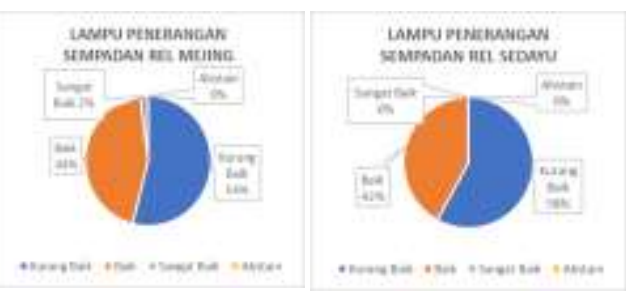

Gambar 9. Penilaian masyarakat tentang fasilitas lampu penerangan Sumber: Hasil analisis penulis

Dari grafik penilaian responden mengenai lampu penerangan ruang publik di sempadan rel Mejing dan Sedayu, keduanya menduduki penilaian yang hampir sama. Di sempadan rel Mejing terdapat $44 \%$ responden yang menilai lampu penerangan baik dan $54 \%$ menilai kurang baik. Hampir sama dengan penilaian responden di sempadan rel Sedayu, $42 \%$ responden menilai lampu penerangan sudah baik dan $58 \%$ responden menilai kurang baik. Ada beberapa titik di area ruang publik yang tidak mendapat cahaya penerangan lampu ruang sempadan rel. Karena lampu penerangan di sini, bukan semata-mata untuk memfasilitasi ruang publik yang terbentuk, akan tetapi sebagai fasilitas penerangan untuk jalan umum.

Kapasitas area parkir dan pengelolaan parkir termasuk ke dalam indikator kenyamanan yang dapat dijadikan tolok ukur sebuah ruang publik yang baik.
Penilaian responden mengenai fasilitas parkir di kedua sempadan rel adalah sebagai berikut:

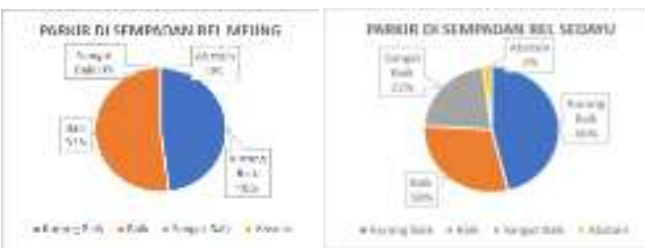

Gambar 10. Penilaian masyarakat tentang fasilitas parkir

Sumber: Hasil analisis penulis

Hasil penilaian fasilitas parkir di sempadan rel Mejing adalah 52\% responden menilai sudah baik dan $48 \%$ responden menilai kurang baik. Sedangkan penilaian di sempadan rel Sedayu $22 \%$ responden menilai sangat baik, 30\% responden menilai $30 \%$ baik dan $46 \%$ kurang baik. Eksisting yang ada di sempadan rel Mejing dan Sedayu tidak ada fasilitas parkir secara khusus, hanya terdapat area yang kosong untuk digunakan sebagai parkir kendaraan pengunjung. Area tanah kosong sempadan rel Sedayu lebih luas dibandingkan sempadan rel Mejing, sehingga kendaraan tidak terlalu mepet dengan rel kereta dan jalan raya seperti pada kondisi sempadan rel Mejing.

Keberadaan pedagang kaki lima di ruang publik sempadan rel Mejing dan Sedayu merupakan salah satu daya tarik utama pengunjung untuk datang ke area ini. Pedagang kaki lima yang ada di sempadan rel ini adalah penjaja kuliner dan pedagang arena permainan bagi anak-anak. Hasil penilaian yang dihasilkan dari kuesioner responden mengenai penataan kaki lima di sempadan rel Mejing dan Sedayu adalah sebagai berikut: 

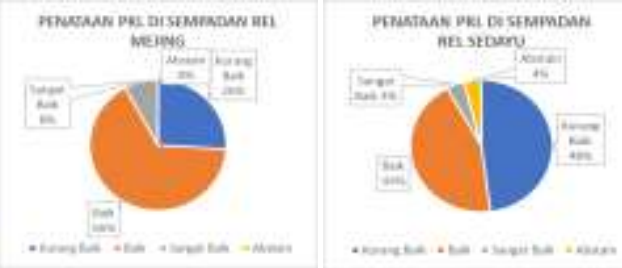

Gambar 11. Penilaian masyarakat tentang penataan PKL

Sumber: Hasil analisis penulis

Sebagian besar pengunjung yang berperan sebagai responden menilai baik $(66 \%)$ untuk penataan PKL di sempadan rel Mejing. Selain itu, terdapat $26 \%$ penilaian kurang baik mengenai penataan PKL di sempadan rel Mejing. Kondisi eksisting PKL di sempadan rel Mejing, ada peruntukan lahannya sendiri, bahkan PKL mempunyai paguyuban, sehingga mereka dapat saling koordinasi satu dengan yang lainnya. Penempatan lokasi berjualan, PKL ini selalu menempati lokasi yang sama untuk berjualan, karena sudah membagi-bagi lokasi sesuai kesepakatan. Sedangkan penilaian penataan PKL di sempadan rel Sedayu, sebanyak $48 \%$ responden menilai kurang baik, $44 \%$ responden menilai baik, dan $4 \%$ responden menilai sangat baik. Kemungkinan yang terjadi, karena lokasi sempadan rel Sedayu yang lokasinya lebih luas, dan jumlah PKL yang tidak menentu, menjadikan penataan PKL tidak ada aturannya seperti PKL di sempadan rel Mejing. Hanya beberapa PKL yang membutuhkan area yang besar seperti arena bermain, yang selalu menempati posisi yang sama di ruang sempadan rel.

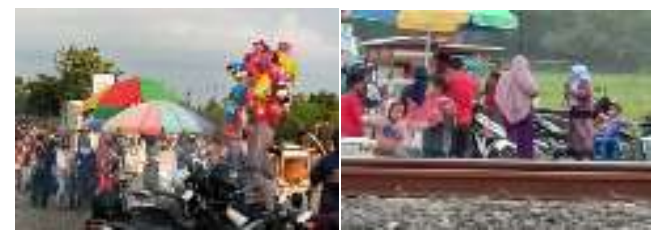

Gambar 12. PKL di lokus

Sumber: Dokumentasi penulis

\section{Relaxation (Relaksasi)}

Ruang publik yang menyediakan area yang meneduhkan untuk berkumpul merupakan salah satu indikator kenyamanan psikologis yang dirasakan oleh pengunjung di lokasi penelitian. Berikut merupakan hasil penilaian responden terhadap indikator ini:

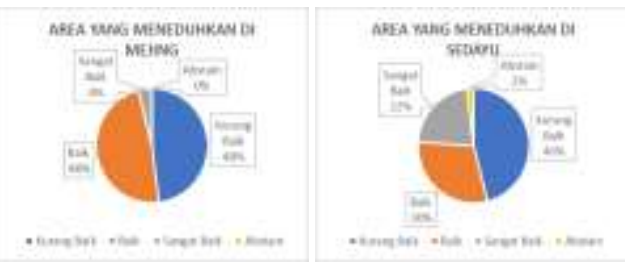

\section{Gambar 13. Penilaian masyarakat tentang area yang meneduhkan \\ Sumber: Hasil analisis penulis}

Hasil penilaian area meneduhkan pada sempadan rel kereta Mejing adalah $48 \%$ responden menilai baik, $48 \%$ responden menilai kurang baik dan $4 \%$ menilai sangat baik. Kondisi eksisting area meneduhkan di sempadan rel Mejing ini, di kanan dan kiri ruang terbuka terdapat beberapa pohon yang bisa dijadikan area untuk berteduh pengunjung saat menikmati suasana di lokasi sembari menikmati kuliner. Sedangkan penilaian area meneduhkan pada sempadan rel Sedayu adalah $46 \%$ responden menilai kurang baik, 30\% menilai baik dan $22 \%$ menilai sangat baik. Sebagian besar responden di Sedayu menilai kurang baik dikarenakan area ruang terbuka yang luas di sempadan ini, di kanan kirinya merupakan area persawahan yang tidak terdapat banyak pohon untuk berteduh. Hanya ada pohon pisang di pinggir 
sempadan dan pohon rindang yang jumlahnya tidak banyak untuk berteduh.

Tatanan dan kerapian tanaman juga mempengaruhi psikologis pengunjung untuk merasakan relaksasi di ruang terbuka publik ini. Penilaiannya adalah sebagai berikut:

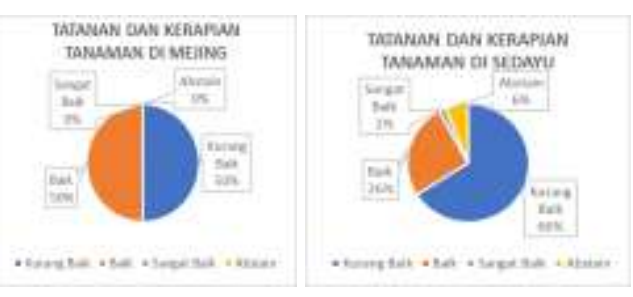

Gambar 14. Penilaian masyarakat tentang penataan tanaman

Sumber: Hasil analisis penulis

Hasil rekap penilaian mengenai tanaman yang ada di sempadan rel Mejing, responden menilai $50 \%$ baik dan 50\%nya lagi menilai kurang baik. Pada keadaan eksistingnya tidak ada penataan secara khusus tanaman di sempadan rel Mejing, hanya beberapa tanaman yang tidak terlalu tinggi berada di pinggiran sempadan, karena peraturan sempadan rel memang tidak memperbolehkan tanaman besar berada di sekitarnya. Untuk tanaman perdu di sekitaran sempadan rel tidak ada penataan juga. Sedangkan penilaian mengenai penataan tanaman di sempadan rel Sedayu, responden menilai $66 \%$ kurang baik, 26\% responden menilai baik, $6 \%$ tidak menjawab pertanyaan dan $2 \%$ menilai sangat baik. Kondisi ruang publik di sempadan rel Sedayu, tidak ada penataan tanaman, dan sebagian besar tanah kosong dijadikan area untuk berdagang PKL.

Indikator relaxation untuk ruang terbuka di sempadan rel yang lainnya adalah kebersihan lokasi yang dapat mempengaruhi kenyamanan dan mendukung relaksasi pengunjung yang mendatangi area terbuka. Hasil penilaian indikator ini adalah sebagai berikut:

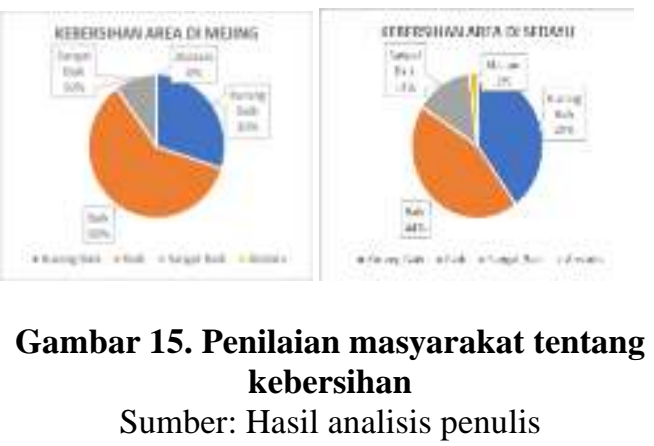

Kebersihan area di sempadan rel Mejing mendapatkan $60 \%$ penilaian baik dari responden. Sedangkan responden lainnya menilai kurang baik terdapat $30 \%$ dan sangat baik $10 \%$. Walaupun kondisi lokasinya belum tertata dengan baik, namun kebersihan memang sudah ada peraturan dari pihak PJKA kepada PKL yang berjualan di area sempadan rel Mejing agar tetap menjaga kebersihan masing-masing area berjualan. Masing-masing PKL mengumpulkan sampah untuk dibuang setelah selesai berjualan. Untuk penilaian kebersihan sempadan rel di Sedayu, hasilnya adalah $44 \%$ responden menilai baik, $40 \%$ kurang baik, dan 14\% sangat baik. Di beberapa titik lokasi, masih ada beberapa tumpukan sampah yang mengganggu pandangan, sehingga hal ini juga mempengaruhi penilaian responden mengenai indikator kebersihan.

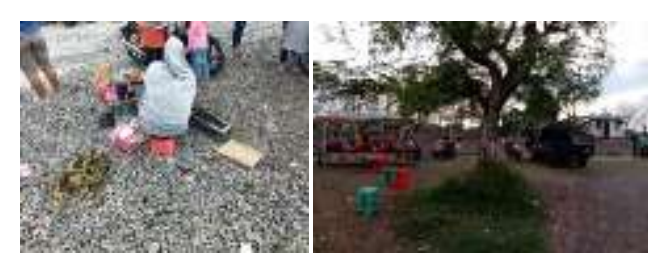

Gambar 16. Kebersihan di lokus Sumber: Dokumentasi penulis 
Dalam kuesioner juga diberikan pertanyaan untuk mengetahui apakah responden dapat menikmati waktu yang dihabiskan di lokasi penelitian. Hasil penilaiannya adalah sebagai berikut:

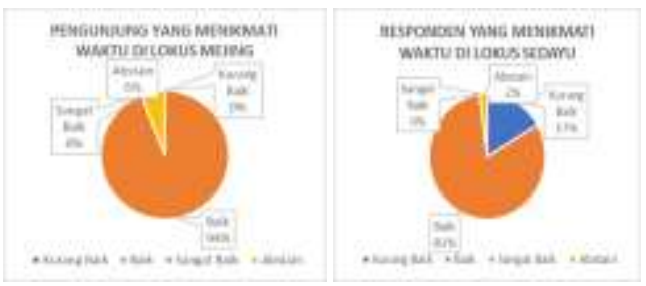

Gambar 17. Penilaian masyarakat dalam menikmati waktu di lokus Sumber: Hasil analisis penulis

Di lokasi sempadan rel Mejing, sebagian besar pengunjung dapat menikmati waktu ketika berada di sempadan rel ini, yaitu 94\% pengunjung merasa baik, dan $6 \%$ tidak menjawab pertanyaan. Sedangkan responden di lokasi Sedayu menjawab $81 \%$ baik, dan $17 \%$ responden lain menjawab kurang baik.

Hasil penilaian responden mengenai keinginan untuk menghabiskan waktu di lokasi sempadan rel Mejing adalah sebagai berikut:

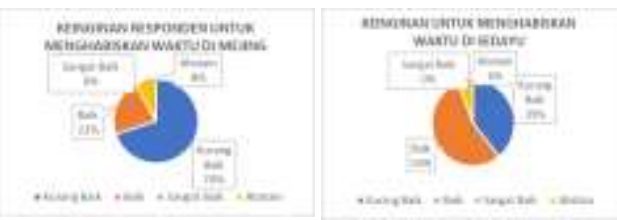

Gambar 18. Penilaian masyarakat dalam keinginan untuk menghabiskan waktu Sumber: Hasil analisis penulis

Di sempadan rel Mejing, 70\% responden menjawab kurang dapat berlama-lama untuk menghabiskan waktu di lokasi, sedangkan 22\% responden menjawab dapat menghabiskan waktu dengan baik di lokasi. Di sempadan rel Sedayu, 55\% responden menjawab dapat menghabiskan waktu dengan baik di lokasi, sedangkan 39\% responden menjawab kurang dapat menghabiskan waktu lama di lokasi.

\section{Passive engagement}

Passive engagement adalah hasil rekap kegiatan yang dilakukan oleh responden, diambil berdasarkan metode amatan dan wawancara. Hasilnya:

\begin{tabular}{|c|c|c|c|c|c|c|}
\hline \multicolumn{7}{|c|}{$\begin{array}{c}\text { Kegiatan Yang Dilakukan } \\
\text { Pengunjung }\end{array}$} \\
\hline \multicolumn{7}{|l|}{ Duduk.. } \\
\hline $\begin{array}{c}\text { SEDAYU } \\
\text { WEEKDAYS }\end{array}$ & 3 & 1 & 7 & 9 & 3 & 10 \\
\hline $\begin{array}{l}\text { SEDAYU } \\
\text { WEEKEND }\end{array}$ & 6 & 7 & 1 & 16 & 4 & 5 \\
\hline $\begin{array}{l}\text { MEJING } \\
\text { WEEKDAKASA }\end{array}$ & & $\mathrm{V} 1$ & ER & ND & 8 & 8 \\
\hline $\begin{array}{l}\text { MEJNGEJ } \\
\text { WEEKEND } \\
\text { =MEJ }\end{array}$ & $\begin{array}{l}\mathrm{NG} \\
\mathrm{NG}\end{array}$ & ? & 4 & AYS & 5 & 2 \\
\hline
\end{tabular}

Gambar 19. Temuan kegiatan di lokus Sumber: Hasil analisis penulis

\section{Active engagement}

Active engagement adalah rekap tujuan responden untuk datang ke lokasi. Hasil rekap dibagi menjadi rekap di hari kerja dan di akhir pekan, dengan hasilnya sebagai berikut:

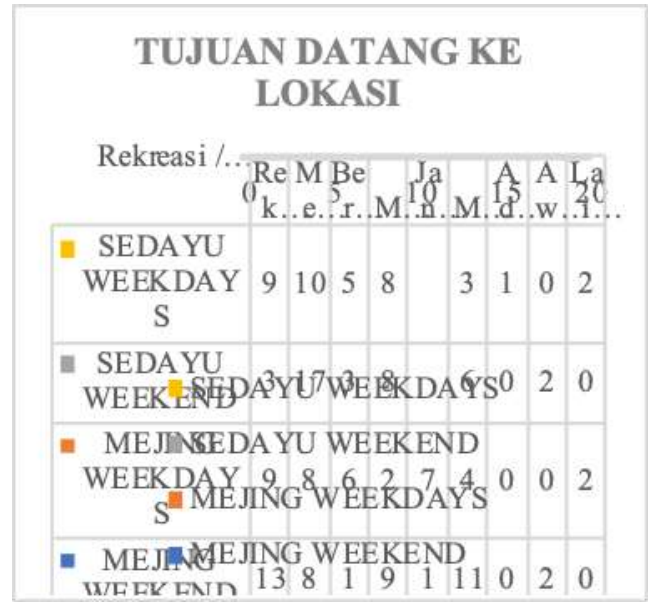

Gambar 20. Temuan tujuan kedatangan di lokus

Sumber: Hasil analisis penulis 


\section{Discovery}

Discovery aktivitas yang ada di sempadan rel kereta api Mejing dan Sedayu adalah keamanan, kenyamanan dan kemudahan yang dirasakan oleh pengunjung saat berada di lokasi penelitian. Indikator pertama yang digunakan adalah keamanan lokasi sebagai tempat bermain anak, karena sebagian besar pengunjung dewasa membawa anak kecil yang datang untuk melihat kereta lewat. Hasil penilaian responden mengenai indikator ini adalah sebagai berikut:
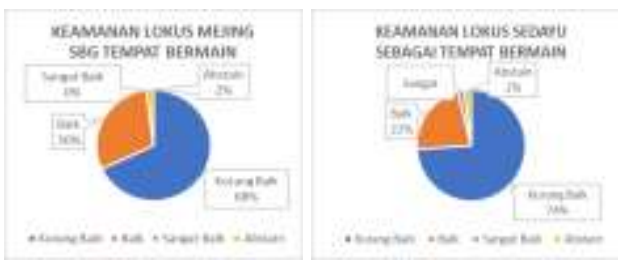

Gambar 21. Penilaian masyarakat tentang keamanan

Sumber: Hasil analisis penulis

Terdapat $68 \%$ pengunjung di sempadan rel Mejing menilai keamanan lokasi sebagai tempat bermain kurang baik karena antara rel kereta yang aktif dan rel kereta yang dijadikan tempat untuk duduk-duduk tidak ada pengaman. Di lain pihak, 30\% responden menilai keamanan lokasi Mejing sebagai tempat bermain baik. Lebih tinggi dari pada sempadan rel di Mejing, 74\% responden di sempadan rel Sedayu menilai keamanan lokus sebagai tempat bermain kurang baik, dan sebanyak $22 \%$ responden menilai keamanan lokasi Mejing sudah baik.
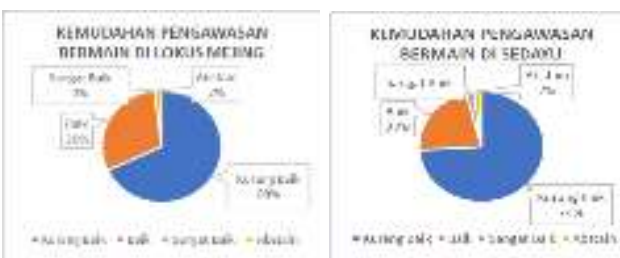

Gambar 22. Penilaian tentang kemudahan pengawasan bermain Sumber: Hasil analisis penulis
Indikator setelahnya adalah kemudahan dalam pengawasan anak bermain. Di sempadan rel kereta api Mejing, responden menilai $68 \%$ responden menilai kurang baik, dan $30 \%$ responden menilai sudah baik. Sebagian besar menjawab kurang baik karena area orang tua untuk dudukduduk adalah di rel kereta, sehingga agak sulit untuk menjangkau anak kecil yang bermain di rel kereta dengan cepat. Hampir sama dengan responden di lokus Mejing, sebanyak $74 \%$ responden di lokus Sedayu juga menilai kemudahan pengawasan anak bermain di sempadan rel ini kurang baik, dan $22 \%$ responden menilai baik.

Hasil dari indikator kenyamanan lokus sebagai tempat berkumpul adalah sebagai berikut:

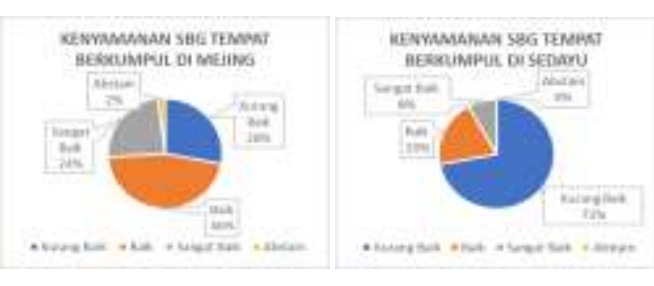

Gambar 23. Penilaian tentang kenyamanan Sumber: Hasil analisis penulis

Responden di lokus Sedayu yang memberikan penilaian mengenai kenyamanan lokus Sedayu sebagai tempat berkumpul, menilai kurang baik sebanyak $72 \%, 20 \%$ responden menilai baik, dan $8 \%$ menilai sangat baik. Sedangkan responden di lokus Mejing menilai lokus Mejing baik sebanyak $46 \%$, kurang baik sebanyak $28 \%$, dan menilai sangat baik $24 \%$.

Hasil dari indikator keamanan sebagai tempat berkumpul di lokus adalah sebagai berikut: 


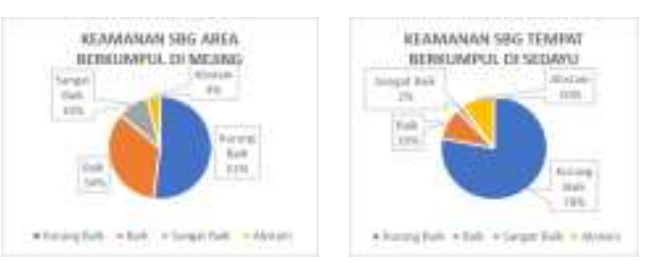

Gambar 24. Penilaian tentang keamanan Sumber: Hasil analisis penulis

$52 \%$ kurang baik untuk keamanan lokus sebagai area berkumpul. Sedangkan sebanyak 34\% responden menilai baik, dan $10 \%$ responden menilai sangat baik. Di lokus Sedayu, sejumlah 78\% responden menilai keamanan lokus Sedayu sebagai tempat berkumpul kurang baik, $10 \%$ responden menilai baik dan hanya $2 \%$ responden yang menilai sangat baik.

Dari masing-masing variable di atas, indikator masing-masing akan disejajarkan agar bisa diidentifikasi. Rentang penilaian yang digunakan adalah antara 0\%-25\% status average nya abstain, $25.1 \%-50 \%$ status average kurang baik, $50.1 \%-75 \%$ status average baik, sedangkan $75.1 \%-100 \%$ status average sangat baik. Hasilnya adalah sebagai berikut:

\section{Sempadan Rel Kereta Mejing}
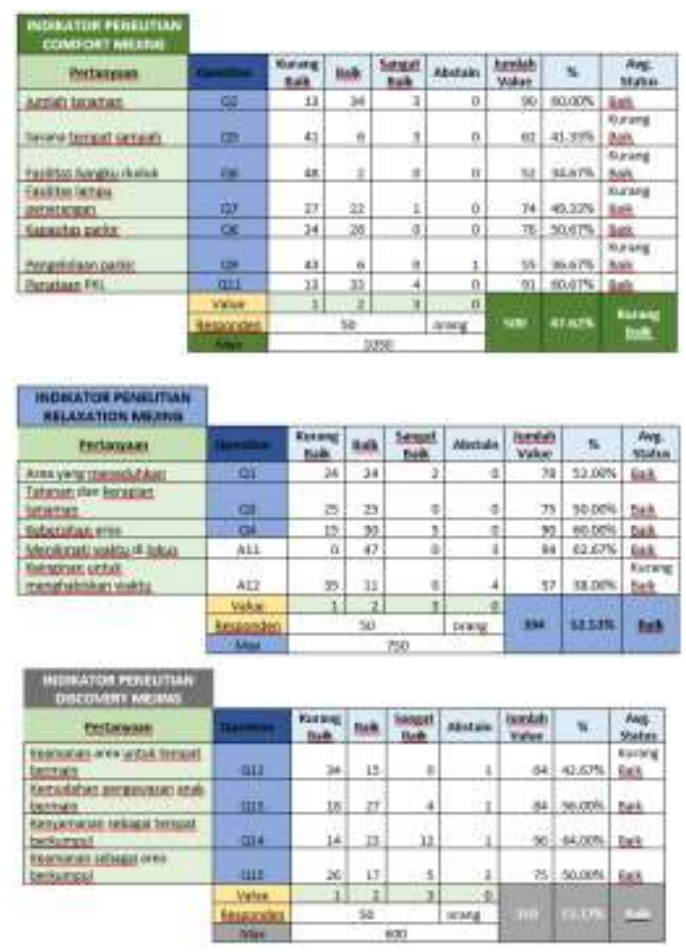

Gambar 25. Hasil penilaian sempadan rel Mejing

Sumber: Hasil analisis penulis

Hasil identifikasi ruang sempadan rel Mejing sebagai ruang terbuka dilihat dari segi kenyamanan dinilai kurang baik, karena hasil penilaian menunjukkan nilai $47,62 \%$. Sebagai sebuah ruang terbuka yang dapat memberikan suasana rileks bagi pengunjung, sempadan rel Mejing mendapatkan penilaian baik dengan angka penilaian sebesar 52,53\%. Sedangkan apabila dilihat dari segi temuan dari aktivitas yang dilakukan di sempadan rel Mejing, hasil penilaiannya adalah baik dengan presentase $53,17 \%$. 


\section{Sempadan Rel Kereta Sedayu}

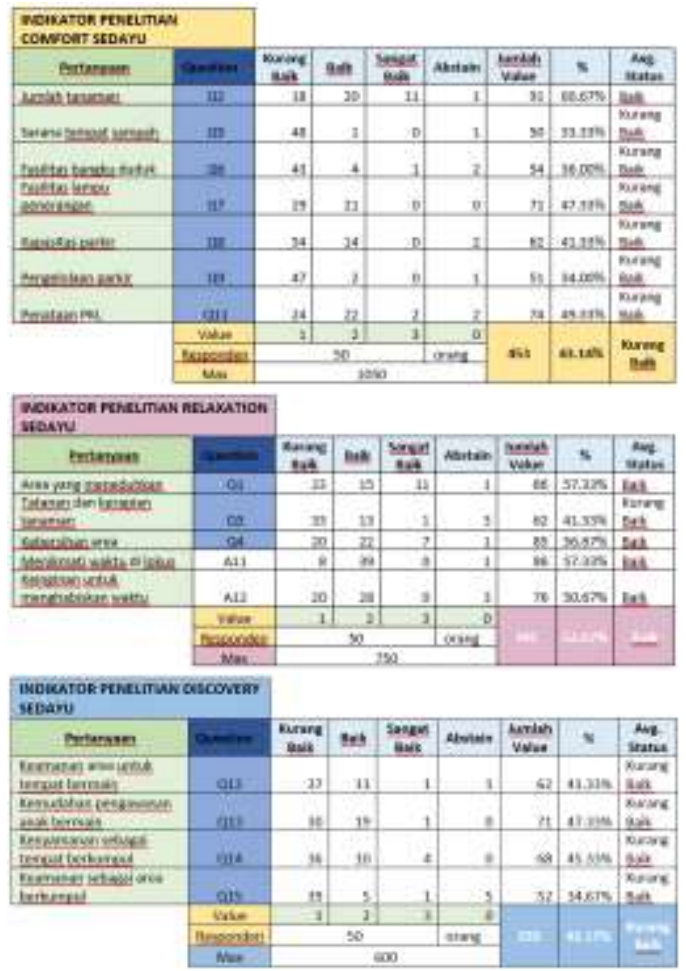

Gambar 26. Hasil penilaian sempadan rel Sedayu

Sumber: Hasil analisa penulis

Berbeda dengan Hasil identifikasi ruang sempadan rel Mejing, ruang sempadan rel Sedayu sebagai ruang terbuka dilihat dari segi kenyamanan mendapatkan penilaian sebesar $43,14 \%$ yang berarti mempunyai nilai kurang baik. Jika dilihat dari segi sebuah ruang yang dapat memberikan suasana rileks bagi pengunjung, mendapatkan penilaian sebesar $52,67 \%$ yang berarti sebagai ruang terbuka publik, sempadan rel Sedayu dapat memberikan suasana rileks dan menyenangkan bagi pengunjung. Sedangkan dilihat dari hasil temuan aktivitas yang ada di sempadan rel Sedayu, hasilnya adalah kurang baik dengan angka penilaian sebesar $42,17 \%$.

\section{Kesimpulan}

Dari hasil data lapangan yang dilakukan oleh penulis pada 2 (dua) area Ruang Terbuka Publik di sempadan rel kereta api Mejing dan Sedayu, penulis dapat menyimpulkan beberapa hal:

a. Ada kecenderungan masyarakat menggunakan lost space untuk kebutuhan mereka berinteraksi. Dalam kasus ini, lost space yang digunakan untuk memenuhi kebutuhan masyarakat berinteraksi adalah area sempadan rel yang lokasinya mudah dijangkau, area nya luas, dan terdapat hiburan melihat kereta api yang melintas.

b. Ruang terbuka publik di sempadan rel Mejing, jika dilihat dari segi kenyamanan mendapatkan penilaian yang kurang baik dengan presentase $47,62 \%$ karena fasilitas tempat duduk, tempat sampah, area berteduh dan area aman dari rel kereta belum tersedia, sehingga pengunjung merasa kurang nyaman bisa berlama-lama di lokasi. Sedangkan di ruang terbuka publik di sempadan rel Sedayu mendapatkan penilaian kurang baik dengan presentase sebesar 43,14\%.

c. Secara umum jika dilihat dari indikator relaxation, ruang terbuka di sempadan rel Mejing dan Sedayu mendapat penilaian baik dengan presentase $52,53 \%$ dan $52,67 \%$. Presentase relaxation ini dipengaruhi oleh situasi area yang mendukung pengunjung untuk dapat menikmati ruang publik dengan berlama-lama sambal menikmati suasana sore dan kereta yang melewati rel.

d. Sedangkan tingkat keamanan ruang terbuka di sempadan rel Mejing menyatakan penilaian baik dengan rata-rata presentase $53,17 \%$ dan di sempadan rel Sedayu mendapatkan 
penilaian kurang baik dengan nilai presentase $42,17 \%$. Faktor keamanan yang dinilai oleh responden lebih bersifat subjektif kepada keamanan tempat bermain anak, keamanan keadaan pagar di pinggir rel kereta, dan keamanan area parkir.

\section{Rekomendasi}

Berdasarkan hasil temuan penelitian, maka melalui penelitian ini, penulis merekomendasikan beberapa hal, yaitu:

a. Perlunya perhatian dari pemerintah wilayah mengenai masalah pengadaan dan kelayakan ruang terbuka publik, untuk memberikan pengelolaan dan pemeliharaan fasilitas publik yang lebih baik. Karena secara tidak langsung masyarakat akan menggunakan lost space untuk area publik sebagai area saling berinteraksi.

b. Perlunya keterlibatan masyarakat atau Lembaga swadaya kemasyarakatan untuk ikut berperan dalam perawatan ruang terbuka di sempadan rel kereta api khususnya di Mejing dan Sedayu ini.

\section{Daftar Pustaka}

Carmona, Mattew, et al. (2010). Public places urban spaces. UK: Architectural Press.

Darmawan, Edy. (2009). Ruang publik dalam arsitektur kota. Semarang: Badan Penerbit Universitas Diponegoro.

Dirjentaru. (2008). Peraturan Menteri Pekerjaan Umum Nomor: 05/PRT/M/2008 tentang Pedoman Penyediaan dan Pemanfaatan Ruang Terbuka Hijau di Kawasan Perkotaan. Departemen Pekerjaan Umum.
Hakim, Rustam. (1987). Unsur perancangan dalam arsitektur lansekap. Jakarta: Bina Aksara.

Rahmadi, Muhamad Harry. (2017). Survey kenyamanan dan keamanan ruang terbuka hijau (rth) publik di kota samarinda. Jurnal Ilmu Administrasi, Vol. 14 No. 1, 113-125. 